\title{
PSIKOLOGI HUMANIS; Mengurai Relasi Teoritik antara Psikologi dan Agama
}

\author{
Rangga Sa'adillah S.A.P.1, Daiyatul Khusnah², Dewi Winarti \\ ISTAI Taswirul Afkar Surabaya 2, 3PW Fatayat NU Jawa Timur
}

\begin{abstract}
ABSTRAK
Diskursus psikologi dapat dilacak melalui pemikiran filosof muslim seperti Al-Kindi, Al-Farabi, Ibn Sina, dan Al-Ghazali tentang konsep nafs. Strukturnya yang abstrak tetapi nyata membentuk psikis manusia, mendapat sambutan yang hangat dari pemikir-pemikir Barat seperti Wilhelm Wundt dan Ivan Pavlov sehingga lahir ilmu psikologi. Ajaran Islam tentang kejiwaan dan ilmu psikologi bukan dua hal yang berbeda akan tetapi saling menopang satu sama lain dan melengkapi, sebab dalam perkembangan ilmu psikologi ada pasang surut relasi antara psikologi dengan agama. Melalui kajian multidisipliner pendidikan agama Islam, artikel ini menguraikan terminologi psikologi Islam; elemenelemen psikologis manusia; dan unsur penggerak manusia. Akhir dari artikel ini penulis mencoba mencari muara antara psikologi barat dengan ajaran Islam tentang kejiwaan yang berujung pada psikologi humanis. Psikologi humanis merupakan periode mutakhir dari proses pasang surut relasi antara psikologi dengan agama. Psikologi humanis mampu menjadi mainstream baru dalam memahami manusia bukan hanya terkait dengan kejiwaannya melainkan juga motivasi penggerak dan sisi spiritualitas manusia yang tidak mampu dijangkau oleh psikologi eksperimental.
\end{abstract}

Kata Kunci: Psikologi Islam, Pendidikan Agama Islam, Filsafat Islam, Psikologi Humanis

\section{ABSTRACT}

Psychological discourse can be traced through the thoughts of Muslim philosophers such as Al-Kindi, Al-Farabi, Ibn Sina, and Al-Ghazali about the concept of the nafs. Its abstract but real structure forms the human psyche, received a warm welcome from Western thinkers such as Wilhelm Wundt and Ivan Pavlov so that psychology was born. Islamic teachings about psychology and psychology are not two different things but mutually support each other and complement each other, because in the development of psychology there are ups and downs in the relationship between psychology and religion. Through a multidisciplinary study of Islamic religious education, this article describes the terminology of Islamic psychology; human psychological elements; and the human driving force. At the end of this article, the author tries to find an estuary between western psychology and Islamic teachings on psychology which leads to humanist psychology. Humanist psychology is the latest period of the ebb and flow of the relationship between psychology and religion. Humanist psychology is able to become the new mainstream in understanding humans not only related to their psychology but also the driving motivation and side of human spirituality that experimental psychology cannot reach.

Keywords: Islamic Psychology, Islamic Religious Education, Islamic Philosophy, Humanist Psychology

\section{A. Pendahuluan}

Umumnya pakar psikologi sepakat bahwa psikologi menjadi disiplin ilmu pengetahuan tatkala Wilhelm Wundt (1832-1920) mendirikan laboratorium psikologi yang pertama di Universitas Leipzig, Jerman, tahun 1879. Sebelum menjadi maestro Psikologi, ia dikenal sebagai seorang sosiolog, filsuf dan ahli hukum, hingga ia menulis sebuah karya yang berjudul Bitiagen Zur Theorie der Sines Wahrenmung (Persepsi yang dipengaruhi oleh kesadaran), 1862 dan Grund Zuge der Physiologischen Psychologie (dasar fisiologis dari gejala-gejala psikologis) sejak saat itulah ia disebut sebagai 
systematic psychologist dan seorang experimentalis. ${ }^{1}$ Pada awal periode ini ciri utama perkembangan psikologi adalah pengembangan psikologi secara observasi dan eksperimen di laboratorium. Perhatian utama tertuju pada tingkahlaku manusia secara umum. $^{2}$

Ivan Pavlov (1849-1936), melakukan hal serupa dengan Wundt dengan melakukan kajian psikologi secara eksperimental. Seorang mantan pendeta yang menghabiskan sepanjang hidupnya mempelajari fisiologi tersebut pada usia 50 tahun. ${ }^{3}$ Pavlov menggunakan cara pembedahan pada anjing yang memungkinkan cairan perut mengalir melalui suatu hiliran (fistula) keluar dari tubuh, agar cairan itu ditampung. Tatkala Pavlov mengukur sekresi perut saat anjing merespons bubuk makanan, ia mengobservasi bahwa anjing dapat mengeluarkan air liur hanya dengan melihat makanan. Selain itu, saat mendengar langkah kaki eksperimenter si anjing juga mengeluarkan air liur. Pada awalnya, Pavlov menyebut respons itu sebagai refleks "psikis." Sebagai ilmuwan yang amat objektif dan sebagai fisiologis, Pavlov pada mulanya enggan meneliti refleks "psikis." Tetapi setelah bergulat lama ia akhirnya memutuskan untuk mempelajari isu tersebut. Olson (1997) memberikan keterangan bahwa studi yang dilakukan oleh Pavlov diwujudkan dalam bentuk buku berjudul Conditioned Reflexes and Psychiatry (1941). ${ }^{4}$

Eksperimen yang dilakukan oleh Pavlov dengan media anjing menjadi wajar, sebab menurut Dalyono, ${ }^{5}$ sebelum menjadi disiplin ilmu yang mandiri, Psikologi memiliki akar-akar yang kuat dalam ilmu kedokteran dan filsafat. Dalam kedokteran, psikologi berperan menjelaskan apa yang terpikir dan terasa oleh organ-organ (jasmani). Sedangkan dalam filsafat, yang sebenarnya "ibu kandung” psikologi itu berperanserta dalam memecahkan masalah-masalah rumit yang berkaitan dengan akal, kehendak, dan pengetahuan. Karena kontak dengan berbagai disiplin itulah, maka timbul bermacam-macam definsi psikologi yang satu sama lain berbeda, seperti (1) psikologi adalah ilmu mengenai kehidupan mental, (2) psikologi adalah ilmu mengenai akal pikiran, (3) psikologi adalah ilmu mengenai tingkah laku (the science of behavior), dan lain-lain definisi yang sangat bergantung pada sudut pandang yang

${ }^{1}$ Abdur Rahman Shaleh \& M. A. Wahab, Psikologi Suatu Pengantar Dalam Perspektif Islam (Jakarta: Kencana, 2004).

2 Baharuddin, Paradigma Psikologi Islami Studi Tentang Elemen Psikologi Dari Al-Quran (Yogyakarta: Pustaka Pelajar, 2004).

3 Nia Indah Purnamasari, "Signifikansi Teori Belajar Clark Hull dan Ivan Pavlov bagi Pendidikan Islam Kontemporer”, Qudwatuna: Jurnal Pendidikan Islam, Vol. 3, No. 1, (2020): 1-24.

${ }^{4}$ M. H. Hergenhahn, B. R., \& Olson, An Introduction to Theories of Learning, P. Janzow. (New Jersey: PrenticeHall International, Inc., 1997).

${ }^{5}$ Dalyono, Psikologi Pendidikan, Vol. Cet. (Jakarta: PT Rineka Cipta, 2005).

El Banat Vol. 11 No. 1 (2021)

18 
mendefinisikannya. Pada dasarnya, psikologi menyentuh banyak bidang kehidupan diri organisme baik manusia maupun hewan. Psikologi dalam hal ini berhubungan dengan penyelidikan mengenai bagaimana dan mengapa organisme-organisme itu melakukan apa yang mereka lakukan. Namun secara khusus, psikologi lebih banyak dikaitkan dengan kehidupan organisme manusia. Dalam hubungan ini, psikologi definisikan sebagai ilmu pengetahuan yang berusaha memahami perilaku manusia, alasan dan cara mereka melakukan sesuatu, dan juga memahami bagaimana makhluk tersebut berpikir dan berperasaan.

Kajian atas perilaku manusia pada psikologi didominasi oleh aliran behavioris, yang mendasarkan anggapannya pada realitas empiris dan objektif melalui eksperimen. Periode ini membawa psikologi fokus pada kajian perilaku atau tingkah laku yang tampak pada manusia (overt behavior). Akan tetapi kajian ini tidak mampu menyentuh aspek non-empiris. Bahwa manusia itu semua aksi dan kekuatannya dikendalikan oleh kekuatan hidup. Psikologi terus berkembang merambah pada kajian kognitif, aliran ini tidak hanya mengkaji manusia sebagai homo sapiens, akan tetapi menempatkan manusia sebagai homo ludens yang penekanannya difokuskan pada makna yang ada dibalik diri manusia. Dengan kata lain, ada yang menggerakkan manusia selain pemicu respon adalah pikirannya, jiwanya. ${ }^{6}$

Perbincangan tentang jiwa mendapat tempat tersendiri dikalagan filosof muslim perioode awal seperti Al-Kindi, Al-Farabi, Ibn Sina, dan Al-Ghazali. Mereka memperbincangkan bahwa jiwa merupakan struktur psikologis yang membentuk tindakan manusia. Oleh karena itu, filosof muslim tegas membedakan antara jiwa dengan nyawa. ${ }^{7}$ Nyawa adalah daya jasmaniah yang adanya tergantung pada hidup jasmani dan menimbulkan perbuatan badaniah (organic behavior), yaitu perbuatan yang ditimbulkan oleh proses belajar. Misalnya instink, refleks, nafsu, dan sebagainya. Jika jasmani mati, maka mati pulalah nyawanya. Sedangkan jiwa adalah daya hidup rohaniah yang bersifat abstrak, yang menjadi penggerak dan pengatur bagi sekalian perbuatan-perbuatan pribadi (personal behavior) dari hewan tingkat tinggi dan manusia. Karena sifatnya abstrak, maka kita tidak dapat mengetahui jiwa secara wajar, melainkan kita hanya dapat mengenal gejalanya saja. Jiwa adalah sesuatu

\footnotetext{
${ }^{6}$ R. Sapuri, Psikologi Islam Tuntunan Jiwa Manusia Modern (Jakarta: PT Raja Grafindo Persada, 2009).

7 Afrizal M, "Pemikiran Para Filosof Muslim Tentang Jiwa," An-Nida - Jurnal Pemikiran Islam 39, no. 1 (2014): 1-17; Rangga Sa'adillah S.A.P., Dewi Winarti, and Daiyatul Khusnah, "Kajian Filosofis Konsep Epistemologi Dan Aksiologi Pendidikan Islam," Journal of Islamic Civilization 3, no. 1 (2021): 34-47, https://journal2.unusa.ac.id/index.php/JIC/article/view/2135.
} 
yangn tidak tampak, tidak dapat dilihat oleh alat. Demikian pula hakikat jiwa, tak seorang pun dapat mengetahuinya. ${ }^{8}$

Menjadi suatu pertanyaan yang menggelitik, siapakah penggerak jiwa? Mengapa jiwa selalu mengarah pada keseimbangan? dan bagaimana menjelaskan dimensidimensi mistik pada manusia? Baharuddin menjawab, sekitar tahun 1975, muncul kesadaran dikalangan psikolog Muslim atas paradigma yang dikembangkan Barat. Mereka menyadari bahwa psikologi yang dikembangkan di dunia Barat memiliki ciri-ciri antara lain: pertama, menafikan dimensi Tuhan dalam kajian psikologi. Kedua, epistemologi yang digunakan terfokus pada empiris positivistic dan empiris humanistik. Ketiga, tidak mengungkap ruh sebagai struktur utama kepribadian manusia. Keempat, berpusat pada anthropo-sentris. Karakteristik psikologi seperti itu, tidak begitu saja diterapkan dalam memahami, menelaah, dan memprediksi tingkah laku umat Islam, yang dalam kehidupan sehari-hari tidak dapat memisahkan diri dengan keyakinannya kepada Tuhan.

Menurut Baharuddin, ${ }^{10}$ persentuhan antara psikologi dengan agama berlangsung pasang surut, ia membagi menjadi empat periode. Periode pertama berlangsung paruh kedua abad ke-19, periode maestro psikologi Wilhelm Wundt periode awal ini psikologi masih berkutat pada analisis tingkah laku manusia, masalah agama tidak mendapat perhatian serius. Periode kedua berlangsung akhir abad ke-19 sampai awal abad ke-20. Ciri utama periode ini adalah usaha-usaha psikolog untuk mengkaji dan menafsirkan perilaku beragama berdasarkan konsep dan teori psikologi. Periode ketiga berlangsung sejak 1930 sampai sekitar 1950-an. Periode ini adalah kemerosotan relasi antara agama dengan psikologi. Periode keempat dimulai sekitar tahun 1960-an hingga saat ini. Periode ini adalah pengembangan psikologi yang mengarah pada usaha-usaha untuk menjadikan nilai budaya dan agama sebagai objek kajian psikologi dan juga sekaligus sebagai sumber inspirasi bagi pembangunan teori-teori psikologi.

\section{B. Mencermati Terminologi Psikologi Islam}

Proyek Islamisasi sains yang dipelopori oleh Al-Faruqi berimbas pada sebagian besar sains, tak terkecuali psikologi. Al-Faruqi mendefinisikan Islamisasi Ilmu

\footnotetext{
8 Rivai Bolotio, “Analisis Pendidikan Dalam Konsep Pendidikan Jiwa,” 2000; Abu Ahmadi \& W. Supriyono, Psikologi Belajar (Jakarta: PT Rineka Cipta, 2013); Fatimah Halim, "Kajian Kritis Terhadap Pemikiran Tentang Jiwa (Al-Nafs) Dalam Filsafat Islam," Al Daulah: Jurnal Hukum Pidana dan Ketatanegaraan 1, no. 2 (2013): 60-73, http://journal.uin-alauddin.ac.id/index.php/al_daulah/article/view/1424/1379.

${ }^{9}$ Baharuddin, Paradigma Psikologi Islami Studi Tentang Elemen Psikologi Dari Al-Quran.

10 Ibid.
} 
Pengetahuan berarti upaya integrasi wawasan pengetahuan yang harus ditempuh sebagai awal proses integrasi kehidupan kaum muslimin. Pengintegrasian baru tesebut selanjutnya dimasukan dimasukkan ke dalam keutuhan warisan Islam dengan melakukan eliminasi, reinterpretasi dan adaptasi terhadap komponen-komponenya sebagai sebuah world view of Islam (pandangan hidup Islam) dan menetapkan nilainilainya, serta adanya relevansi yang eksak antara Islam dengan filsafat, dan metode dan obyek-obyeknya. ${ }^{11}$ Berkaitan dengan terminologi psikologi Islam, apakah istilah ini muncul akibat islamisasi sains atau ketidakmampuan paradigma psikologi Barat dalam memahami elemen-elemen psikis manusia yang bersifat ghaib.

Sapuri $^{12}$ lebih nyaman menggunakan termonologi psikologi Islami dengan bertumpu pada tiga pendapat. Pendapat pertama dan kedua dari Djamaluddin Ancok dan Fuad Nashori tidak menyebut dengan terminologi psikologi Islam, akan tetapi psikologi Islami dengan mengartikan sebagai perspektif Islam terhadap psikologi modern dengan membuang konsep-konsep yang tidak sesuai dan bertentangan dengan Islam. Pendapat yang ketiga dari Hana Djumhana Bastaman, mendefinisikan psikologi Islami dengan corak psikologi berdasarkan citra manusia menurut ajaran Islam, yang mempelajari keunikan dan pola perilaku manusia sebagai ungkapan pengalaman interaksi dengan diri sendiri, lingkungan sekitar, dan alam kerohanian, dengan tujuan meningkatkan kesehatan mental dan kualitas keberagamaan.

Purwanto $^{13}$ memberikan pandangan mengenai term psikologi Islam. Menurutnya, Islam memberikan khazanah yang tidak terbatas bagi ilmu psikologi. Meskipun awalnya tidak dijumpai istilah psikologi, tetapi dikenal di dalam dunia Islam sebagai ilmu al-Nafs, atau pada masa lalu dikenal dengan Ilmu al-Akhlaq dan tasawuf yang tidak bicara teoretis, tetapi lebih aplikatif yang mewarnai kehidupan kaum muslim hingga sekarang ini. Konsep-konsep demikian ini banyak dijumpai melalui pemikiran-pemiikiran dari Al-Kindi, Al-Farabi, Ibn Sina, dan Al-Ghazali. ${ }^{14}$ Semua perangkat ilmu tersebut dapat direkonstruksi ulang dengan menambah khazanah psikologi kontemporer. Jadi berangkatnya dari khazanah Islam baru menggunakan

\footnotetext{
11 Ismail Raji Al-Faruqi, Islamization of Knowledge General Principle and Work Plan (Bandung: Pustaka Pelajar, 1984); Rangga Sa'adillah S.A.P. et al., "The Meaning Construction of a Scientific Approach on Teaching Islamic Education," International Journal of Psychosocial Rehabilitation 24, no. 09 (2020): 2525-2532.

12 Sapuri, Psikologi Islam Tuntunan Jiwa Manusia Modern.

${ }^{13}$ Y. Purwanto, Epistemologi Psikologi Islami Dialektika Pendahuluan Psikologi Barat Dan Psikologi Islami, ed. A. Susana (Bandung: PT Refika Aditama, 2007).

${ }^{14}$ M, "Pemikiran Para Filosof Muslim Tentang Jiwa"; Bolotio, “Analisis Pendidikan Dalam Konsep Pendidikan Jiwa."
} 
psikologi kontemporer sebagai kerangka saintifikasi agar dikomunikasikan secara universal.

\section{Membedah Elemen-Elemen Psikologis Manusia}

Manusia sebagai makhluk Allah yang istimewa yang menyandang gelar sebagai khalifah Allah di atas muka bumi yang diciptkan Allah melebihi dari makhluk-makhluk lainnya. Al-Qur'an menjelaskan bahwa manusia diciptakan dari tanah, kemudian setelah sempurna kejadiannya, Allah menghembuskan padanya ruh ciptaan-Nya (QS. Al-Shad: 71-72). Dengan "tanah" manusia dipengaruhi oleh kekuatan alam seperti makhluk-makhluk yang lain, sehingga butuh makan, minum, hubungan seks dan sebagainya. Dan dengan ruh dia di antar kea rah tujuan non materi yang tak berbobot, tak bersubstansi dan tak dapat diukur di laboratorium. Al-Qur'an tidak memandang manusia sebagai makhluk yang tercipta secara kebetulan atau tercipta dari kumpulan atom, tapi ia diciptakan setelah sebelumnya direncanakan untuk mengemban satu tugas, "sesungguhnya Aku hendak menjadikan khalifah dimuka bumi”, (QS. Al-Baqarah: 30). la dibekali Allah dengan potensi dan kekuatan positif untuk mengubah corak kehidupan ke arah lebih baik (QS. Al-Ra'd: 11), serta ditundukkan dan dimudahkan kepadanya alam raya untuk dikelola dan dimanfaatkan (QS. Al-Jatsiyat: 12-15), ditetapkan arah yang harus ia tuju (QS. Al-Dzariyat: 56), dianugerahkan kepadanya bashirah untuk menjadi pelita dalam perjalanannya menuju dimensi eskatologis. ${ }^{15}$

Objek formal telaah psikologi adalah manusia. Objek materialnya adalah telaah tingkah laku manusia. Berdasarkan itu, maka persoalan fundamental (dasar) dalam psikologi adalah persoalan manusia. Konsep manusia menjadi pure science (filsafat sains) bagi teori-teori psikologi. ${ }^{16}$ Apabila psikologi Islam memandang manusia sebagai makhluk yang unik, berbeda dengan aliran-aliran psikologi Barat. Dalam garis besarnya ada tiga aliran psikologi, yaitu Psikoanalisa yang memandang manusia sebagai makhluk yang dikuasai oleh sistem unconsciousness (ketidaksadaran) dalam diri manusia. Behaviorisme, memandang manusia sebagai makhluk biologis yang terkondisi oleh lingkungan. Sedangkan humanis, memandang bahwa manusia adalah makluk unik

15 Wahab, Psikologi Suatu Pengantar Dalam Perspektif Islam; Rangga Sa'adillah Sandhy Atma Putra, “Pendekatan Saintifik Dalam Perspektif Pendidikan Islam” (Universitas Islam Negeri Sunan Ampel Surabaya, 2014), http://digilib.uinsby.ac.id/846/; Rangga Sa'adillah Sandhy Atma Putra, “Pembelajaran Pendidikan Agama Islam Melalui Pendekatan Saintifik Dalam Membentuk Sikap Spiritual Siswa Sekolah Menengah Atas Di Sidoarjo (Studi Fenomenologi Pengalaman Guru Dan Siswa Pada SMA Di Sidoarjo)" (Universitas Muhammadiyah Malang, 2020), http://eprints.umm.ac.id/65683/.

${ }^{16}$ Abd. Azis, Zaini Tamin AR, \& Muksin, "Genealogi Carok di Madura; Perspektif Psikologi Sosial", Al Ibrah:Jurnal Pendidikan dan Keilmuan Islam, Vol. 5, No. 1 (2020). 
(hampir sama dengan psikologi Islam), yang berbeda dengan binatang. Akan tetapi ia memiliki karakteristik kemanusiaan, seperti gagasan, kreatifitas, nilai-nilai dan lainlain. ${ }^{17}$ Cara pandang yang berbeda dari berbagai aliran tersebut, menimbulkan pemahaman yang berbeda mengenai elemen psikologis manusia. Berikut beberapa penjelasan mengenai elemen psikologis manusia dalam perspektif psikologi Islam:

\section{Nafs (Jiwa)}

Diri atau nafs memiliki pemaknaan kata yang banyak, Menurut Mubarok, nafs memiliki arti (1) jiwa, (2) dorongan hati yang kuat untuk berbuat kurang baik, (3) sesuatu yang melahirkan sifat tercela dan perilaku buruk, (4) sesuatu di dalam diri manusia yang menggerakkan tingkahlaku, dan (5) sisi dalam manusia yang dicipta secara sempurna di mana di dalamnya terkandung potensi baik dan buruk. Dari sekian pengertian tersebut dapat digarisbawahi nafs memiliki dua kecenderungan, yaitu (1) baik dan buruk, (2) dorongan tingkah laku. Keduanya adalah indikasi manusia yang tidak selamanya baik atau selamanya buruk. Tidak dibenarkan suatu tindakan (persepsi) pendewaan kepada seseorang yang sedang baik atau penghinaan kepada yang kebetulan berbuat salah. Selain jalur hukum dan para penegak hukum, tidak dibenarkan orang mengungkit aib orang lain memvonis seseorang yang melakukan kesalahan. ${ }^{18}$

Majid sedikit berkomentar tentang jiwa, bahwa ketulusan ikatan jiwa perlu kepada keyakinan bahwa makna dan hakikat hidup manusia pasti akan menjadi kenyataan dalam kehidupan abadi, kehidupan setelah mati dalam pengalaman bahagia atau sengsara. Kondisi hati anak manusia di dunia adalah gambaran akan nasibnya kelak di akhirat, saat dimana tidak ada lagi hal yang dapat disembunyikan oleh akal atau ekspresi wajah (facial expression). ${ }^{19}$

Melengkapi pendapat di atas, Baharuddin ${ }^{20}$ menjelaskan bahwa nafs adalah bagian dari aspek nafsiah pada diri manusia. Aspek nafsiah merupakan daya psikis khas manusia yang berupa pikiran, perasaan, dan kemauan bebas. Ada beberapa jenis nafsu pertama adalah nafsu ammarah, yaitu nafsu yang memiliki tiga daya, alghaziyah (makan), al-munmiyah (tumbuh), dan al-muwallidah (reproduksi); yang kedua adalah nafsu al-lawwamah, yaitu nafsu yang memiliki daya menerima,

\footnotetext{
${ }^{17}$ Baharuddin, Paradigma Psikologi Islami Studi Tentang Elemen Psikologi Dari Al-Quran.

${ }^{18}$ Desma Husni, "Pengukuran Konsep Amanah Dalam Pendekatan Kualitatif Dan Kuantitatif," Jurnal Psikologi 43, no. 3 (2016): 194-206.

${ }^{19}$ Baharuddin, Paradigma Psikologi Islami Studi Tentang Elemen Psikologi Dari Al-Quran.

${ }^{20}$ Ibid.
} 
mendorong dan penggerak. Daya menerima dipahami berdasar Qur'an Surat AlSyams: 8.

Baharuddin ${ }^{21}$ menjelaskan dalam Qur'an Surat Al-Syams: 8 terdapat kata fujur (kejahatan) dan taqwa (kebaikan), maka secara otomatis ia telah memiliki sifat menerima kedua perbuatan tersebut secara netral. Penerimaan itu sangat bergantung pada daya tarik dari fujur dan taqwa. Daya tarik fujur biasanya lebih besar, daripada daya tarik taqwa. Sehingga nafsu al-lawwamah selalu tergoda untuk melakukan kejahatan. Setelah ia melakukan kejahatan, barula ia menyadari dan mencela dirinya. Karena itu ia disebut dengan nafsu al-lawwamah, yaitu nafsu yang mencela dirinya setelah melakukan perbuatan jahat. la memiliki sifat menyesal kemudian, bukan memikirkan sebelum melakukan. Dan yang ketiga nafsu almuthmainnah, nafsu yang memiliki daya menerima sekaligus daya menolak. Kecenderungan nafsu itu pada hal negatif, sementara nafsu muthmainnah daya menolaknya juga lebih besar, sedangkan daya menerima perbuatan positif juga besar, sehingga ia selalu terhindar dari perbuatan jahat dan selalu melakukan perbuatan baik. Ini disebabkan karena nafsu muthmainnah telah suci (tazkiyah) melalui proses tazkiyah al-nafs, sebab kesucian akan senantiasa mendorong pemiliknya untuk melakukan hal-hal yang positif. ${ }^{22}$

\section{Qalb (Hati)}

Rasulullah shalallahu'alayhi wa sallam bersabda, "Ketahuilah bahwa di dalam tubuh ada sekepal daging, kalau itu baik, baiklah seluruh tubuh. Kalau itu rusak, rusaklah seluruh tubuh. Itulah Qalb” (HR. Bukhari dan Muslim). Penjelasan tentang qalb hingga saat ini masih diperdebatkan oleh banyak kalangan. Masingmasing memiliki penjabaran dan penjelasan tersendiri dengan berpegang pada rujukan-rujukan yang jelas berupa Al-Qur'an dan Hadits atau melalui mujahadah, yaitu dengan ilham atau intuisi yang terkadang memang lebih simpel dan lebih mengena dan bahkan lebih dapat menyentuh lubuk hati daripada penjelasan yang sudah jelas atau terang.

Qalb menurut Al-Ghazali, adalah unsur halus yang bersifat ke-Tuhan-an dan metafisik yang berada pada bentuk hati yang bersifat jasmani. Dengan hati manusia mampu menembus rahasia alam gaib dan nilai-nilai Ilahiyah. Menurut Mubarok, qalb

\footnotetext{
21 Ibid.

22 Ibid.; Erna Yudiani, “Dinamika Jiwa Dalam Perspektif Psikologi Islam,” Jia 1 (2013); Halim, "Kajian Kritis Terhadap Pemikiran Tentang Jiwa (Al-Nafs) Dalam Filsafat Islam”; Mubassyirah Bakry, "Konsep Al-Nafs (Jiwa) Dalam Filsafat Islam," Jurnal Al-Asas III, no. 1 (2015): 135-150; S.A.P., Winarti, and Khusnah, “Kajian Filosofis Konsep Epistemologi Dan Aksiologi Pendidikan Islam.”
} 
diucapkan untuk menyebut jantung, bukan hati, sementara untuk hati disebut alKabid. Secara lughawi, qalb berarti bolak-balik, merujuk kepada sifat hati manusia yang tidak konsisten atau bolak-balik. Rasulullah shalallahu'alayhi wa sallam orang yang ma'shum (terpelihara dari dosa) dalam doannya seringkali membaca, "Ya Allah, Yang Maha membolak-balikkan hati, teguhkanlah hati hamba pada agama Engkau." (HR. Ahmad dari Anas radhiyallahu 'anhu).

Melihat eksistensi qalb yang fitrahnya adalah bolak-balik, naik-turun, mengindikasikan adanya getaran (vibrasi) yang menggambarkan kehidupan. Denyutan nadi dan sirkulasi darah dipersatukan dalam gerakan tersebut, diamnya adalah kematian dan getarannya adalah kehidupan. Dibalik itu semua boleh juga digambarkan dengan iman yang naik dan turun. Lazimnya manusia, keimanan juga tidak stabil, manusia diciptakan tetap dalam dua persimpangan kehidupan yang satu ke arah kebaikan dan yang satu kea rah keburukan. Gerakan kedua arah tersebut hendak disikapi bahwa baik dan buruk merupakan garis yang harus diatur secara harmonis. ${ }^{23}$

3. Aql (Akal)

Secara bahasa kata 'aql mempunyai aneka makna. Diantaranya bermakna alhijr atau al-nuha yang berarti kecerdasan. Sedangkan kata kerja ( $f$ 'il) 'aqala bermakna habasa yang berarti mengikat atau menawan. Karena itulah seseorang yang menggunakan akalnya disebut dengan aqil yaitu orang yang dapat mengikat dan menawan. Berdasarkan pengertian tersebut, dipahami bahwa orang yang menggunakan akalnya pada dasarnya adalah orang yang menggunakan akalnya pada dasarnya adalah orang yang mampu mengikat hawa nafsunya, sehingga hawa nafsunya tidak dapat menguasai dirinya. ${ }^{24}$ la mampu mengendalikan dirinya terhadap dorongan nafsu dan juga dapat memahami kebenaran agama, sebab orang yang dapat memahami kebenaran agama hanyalah orang tidak dikuasai nafsunya. Sebaliknya orang yang dikasai nafsunya tidak dapat memahami agama. Ibrahim Madkur, menjelaskan akal adalah sebagai suatu potensi rohani untuk membedakan antara yang haqq dan bathil. Secara rinci lagi ia menjelaskan bahwa akal sebagai penahan hawa nafsu. Dengan adanya akal, manusia dapat mengetahui amanah dan

\footnotetext{
${ }^{23}$ Bahril Hidayat, Psikologi Islam (Pekanbaru, 2014); Wahab, Psikologi Suatu Pengantar Dalam Perspektif Islam; D Tobroni, "Memperbincangkan Pemikiran Pendidikan Islam Dari Idealisme Substantif Hingga Konsep Aktual," Jakart: Prenada Media group (2018).

${ }^{24}$ Asep Abbas Abdullah, Abdul Muhid, and Rangga Sa'adillah, "Dissecting Implicit Meaning in Tembang Dolanan : A Discourse Analysis," LiNGUA: Jurnal Ilmu Bahasa dan Sastra 16, no. 1 (2021): 61-74, https://ejournal.uinmalang.ac.id/index.php/humbud/article/view/10247.
} 
kewajibannya, akal adalah pemahaman dan pemikiran, akal juga merupakan ketunjuk yang membedakan hidayah dan kesesatan, akal juga merupakan kesadaran batin yang berdaya tembus melebihi pengelihatan mata. ${ }^{25}$

Orang yang berakal adalah orang yang mampu menahan dan mengikat hawa nafsunya. Jika hawa nafsunya terikat, jiwa rasionalitasnya mampu bereksistensi. Kata "jiwa" menunjukkan hal yang lain, bisa berupa nafs atau qalb, tapi tidak terlalu keliru jika kiranya orang berakal itu adalah mereka yang telah memahami sesuatu. Berakal merupakan "percikan qalb", artinya ada secercah sinar yang keluar atau membias dari qalb. Pemahaman adalah sesuatu yang mendalam dan membutuhkan perhitungan baik-buruk dan untung-rugi secara fisik dan psikis sehingga tidak mudah bagi seseorang yang sudah memahami hakikat sesuatu untuk melanggar apalagi menentangnya. ${ }^{26}$

Menurut Ma'an Ziyadat, seseorang mampu memperoleh pengetahuan dengan akal ('aql) melalui daya nalar (al-nazar), dengan tabiat (al-thab'u) melalui daya naluriah atau daya alamiah (al-dharuriyah) dan dengan hati (qalb) melalui daya citra rasa (al-dzauqiyah). Akal merupakan fasilitas manusia untuk memahami dan menyampaikan materi atau informasi secara sistematis dan terukur. Kemampuannya tentu terbatas oleh kekurangan seseorang dalam mencurahkan daya-dayanya, baik dalam bentuk verbal atau tulisan. Pembatasan itu sendiri sebenarnya masih relatif dan dinamis, tidak bisa dikondisikan hanya melihat kurun waktu atau zaman kehidupan yang sedang berlangsung saat ini, tapi penting juga dengan membandingkannya dengan masa silam. Bukankah kemampuan mansia dalam menyampaikan pesan baik secara verbal atau tulisan bahkan isyarat terus berkembang dari waktu ke waktu. Itulah contoh perkembangan dinamis suatu alat ukur kemanusiaan berbentuk kognitif yang rasional.

\section{Syahwat (Nafsu Syahwat)}

Syahwat menurut Mubarok, adalah fitrah kecenderungan yang bersifat universal. Menurutnya, menjalankan sesuatu yang mengikuti fitrah ini seperti menyukai lawan jenis, menyayangi anak, dan sebagainya jika dilakukan secara benar (sah dan halal menurut syariat), akan bernilai ibadah atau sekurangkurangnya mubah.

Kesibukan dengan dunia dan dominasi syahwat pada qalbu mewariskan seluruh sifat-sifat tercela. Maka tidak adal harapan untuk bisa taqarrub

\footnotetext{
${ }_{25}$ Baharuddin, Paradigma Psikologi Islami Studi Tentang Elemen Psikologi Dari Al-Quran.

${ }^{26}$ Rosidin, Epistemologi Pendidikan Islam (Yogyakarta: Diandra Kreatif, 2013). 
(mendekatkan diri) kepada Allah, sepanjang sifat-sifat tercela itu tidak diganti dengan sifat-sifat terpuji. Syahwat akan selalu mendorong pemiliknya ke arah negative jika terlalu mendominasi setiap gerak-gerik dan tingkahlaku. Mau tidak mau cara untk memperbaiki diri adalah dengan konsisten menjalankan akhlak terpuji, yaitu lawan dari segala perbuatan yang dianggap buruk oleh syariat. Hakikat dari pengertian akhlak/budi pekerti, menurut Al-Ghazali ialah suatu bentuk dari jiwa yang benar-benar telah meresap dan dri situlah timbulnya berbagai perbuatan dengan cara spontan dan mudah, tanpa dibuat-buat dan tanpa membutuhkan pemikiran dan angan-angan. ${ }^{27}$

Ketika manusia melakukan dosa, itu merupakan kelalaian, maka diperintahkannya untuk secepat mungkin bertaubat agar mendapatkan ampunan dari Allah. Namun yang terjadi biasanya para pendosa justru tenggelam dan larut, merasakan nikmat semu dalam dosa. Thorndike menggunakan istilah hedonistic, yaitu ingin selalu mencari kenikmatan dan menghindari kesakitan. Mereka sebenarnya selalu berpikir utuk tidak memperturutkan nafsu syahwat-nya. Akan tetapi bagi orang yang memperturutkan nafsu syahwat, mereka adalah orang yang mengetahui akan kebenaran dan bahkan mengetahui kesalahan tapi tetap berpaling dari kebenaran.

Allah berfirman:

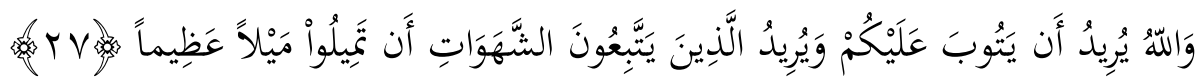

"Dan Allah hendak menerima taubatmu, sedang orang-orang yang mengikuti nafsu syahwatnya bermaksud supaya kamu berpaling sejauh-jauhnya (dari kebenaran)." (QS. Al-Nisa: 27).

Syahwat adalah suatu daya yang berpotensi untuk menginduksi diri dari segala yang menyenangkan. Syahwat dalam terminology psikologi disebut dengan eppetite, yaitu hasrat (keinginan, birahi, hawa nafsu) motif atau implus berdasarkan perubahan keadaan fisiologi. Syahwat yang berarti daya-daya seksual mampu melakukan hubungan seksual dengan memperoleh kenikmatan jasadi, tetapi belum tentu memperoleh kebahagiaan. Semua menjadi terasa bahagia apabila elemen ini berinteraksi dengan qalb. Syahwat bisa bersifat merusak jika dituruti secara berlebihan dan dapat menimbulkan sakit lahiriah, seperti gangguan pada otak, hilang akal, stress, lemah badan, kurus, epilepsi dan penyakit lain yang sejenis. Dengan demikian, syahwat bila terkendali akan berdampak positif dan jika

${ }^{27}$ S.A.P. et al., "The Meaning Construction of a Scientific Approach on Teaching Islamic Education." 
tidak bisa dikendalikan akan merusak dan membahayakan. la seperti seekor kuda liar, jika sudah dapat dijinakkan justru akan membantu tuannya dan mempermudah aktivitasnya. ${ }^{28}$

\section{Hawa (Hawa Nafsu)}

Menurut Mubarok, hawa nafsu adalah dorongan (syahwat) kepada sesuatu yang bersifat rendah, segera dan tidak mengindahkan nilai-nilai moral. Jika seseorang dalam menentukan pilihan lebih dipengaruhi oleh hawa, kecenderungannya adalah pada kenikmatan segera atau pada kenikmatan sesaat, bukan pada kebahagiaan abadi. Jika orang di dalam menentukan pilihan lebih dipengaruhi oleh tuntunan nurani dan agama, pertimbangannya leibh pada meimilih kebahagiaan abadi. Meski untuk itu sudah terbayang harus melampaui terlebih dahulu fase-fase kesabaran dalam menghadapi kesulitan dan kepahitan hidup.

Hidayah Allah subhanahu wa ta'ala, dapat turun kepada siapapun kecuali bagi mereka yang telah berbuat dzalim secara terencana dan terorganisasi. Mereka adalah kelompok (kaum) yang memperturutkan hawa nafsunya sehingga tersesat dalam menjalani hidup. Hidayah telah diberikan kepada seluruh makhluk-Nya. Tanpa hidayah mana mungkin manusia dan makhluk Allah yang lain dapat hidup dengan berbagai macam aktivitas yagn berbeda satu sama lain. Di antara hidayah tersebut adalah matahari yagn memberi petunjuk akan waktu, bulan yagn memberi petunjuk akan hitungan bulan dan bintang yang menjadi petunjuk arah atau mata angina, sedangkan para rasul, para nabi sampai para ulama juga Al-Qur'an dan Hadits adalah petunjuk untuk hati, jalan kehidupan dunia dan akhirat, hati yang gelap atau sakit akan jauh dari kebahagiaan yang sejati, yaitu kebahagiaan dan kesenangan yang tidak merugikan diri sendiri atau makhluk Allah yang ada di sekelilingnya.

Sapuri ${ }^{29}$ menyebutkan ciri-ciri orang yang memperturutkan hawa nafsu: (1) mendustakan Nabi Muhammad shalallahu 'alaihi wa sallam (QS. Al-Nazi'at: 40), (2) tidak mempercayai ketetapan Allah subhanahu wa ta'ala pada setia urusan (QS. AlQamar: 3), (3) selalu menduga-duga (dzann) (QS. Al-Najm: 32), (4) berbicara yang tidak berguna (QS. Al-Najm: 3), (5) memandang baik perilaku buruk (QS. Muhammad: 14), (6) mendustakan para rasul, seperti kaum Bani Israil yang mendustakan para rasul, karena ajaran para rasul bertentangan dengan hawa nafsu mereka (QS. Al-Maidah: 70), dan (7) menyia-nyiakan shalat (QS. Maryam: 59).

\footnotetext{
${ }_{28}$ Purwanto, Epistemologi Psikologi Islami Dialektika Pendahuluan Psikologi Barat Dan Psikologi Islami.

29 Sapuri, Psikologi Islam Tuntunan Jiwa Manusia Modern. 
Adapun dampak buruk bagi mereka yang mengikuti hawa nafsu adalah: (1) hatinya (qalb) akan dikunci mati (thaba'a) oleh Allah (QS. Muhammad: 16), (2) Allah membiarkan orang tersebut tersesat (QS. Al-Jatsiyat: 23), (3) Allah telah mengunci mati pendengaran dan hati orang tersebut dan menutup pendengarannya (QS. AlJatsiyat: 23), dan (4) menyesatkan orang lain (QS. Al-An'am: 119).

Oleh sebab itu hawa nafsu harus dikendalikan melalui mujahadah, yaitu bersusah payah mengeluarkan tenaga untuk memerangi hawa nafsu dan jangan menghiraukan bisikan hawa nafsu. Beberapa ciri bagi orang yang tidak mengindahkan hawa nafsu menurut Sapuri ${ }^{30}$ sebagai berikut: (1) takut kepada kebesaran Tuhan (maqam al-Rabb) (QS. Al-Qamar: 3), (2) mengikuti syariat (QS. AlJastiyat: 18), (3) tidak mengikuti orang yang hatinya telah dilalaikan oleh Allah subhanahu wa ta'ala dari mengingatNya (QS. Al-Kahfi: 28), (4) menjadi saksi karena Alah, biarpun terhadap diri sendiri atau ibu bapak dan kaum kerabat, (5) tidak mendustakan ayat-ayat Allah (QS. Al-An'am: 150), (6) berlomba-lomba dalam berbuat kebajikan (QS. Al-Maidah: 48), (7) memakan makanan yang halal kecuali dalam keadaan terpaksa (idhthirar) (QS. Al-An'am: 119).

\section{Bashirah (Mata Hati)}

Bashirah berarti pandangan mata batin atau pandangan mata hati sebagai lawan dari pandangan mata kepala. Sapuri ${ }^{31}$ menegaskan bahwa ada perbedaan antara hati (qalb) dengan mata hati (bashirah), yaitu pada karakternya. Menurutnya, bila qalb berkarakter tidak konsisten dan menipu diri, pura-pura tidak tahu, sedangkan bashirah selalu konsisten, jujur dan peka.

Menurut Ibnu Qayyim al-Jauziy dalam Sapuri ${ }^{32}$ bashirah adalah cahaya yang ditempatkan Allah di dalam hati manusia (nurun yaqdziquhu Allah fi al-Qalb). Jadi bashirah ditempatkan di dalam qalb memiliki kecenderungan yang konsisten karena ia berada di dalam qalb. Oleh karena itu, orang yang qalb nya sakit, yaitu mereka yang penuh dengan dosa, tentu tidak akan memperoleh pandangan mata hati (bashirah) ini karena ter-hijab (terbatasi) oleh "dinding hitam" atau setidaknya “bintik-bintik hitam" (dosa).

Tentu saja pandangan mata hati akan lebih jauh mendatangkan pemahaman yang mendalam dan lebih akurat daripada pandangan mata kepala. Orang yang mata hatinya telah hidup berarti telah mampu untuk mendiagnosis penyakit orang

\footnotetext{
$30 \mathrm{lbid}$

31 Ibid.

32 Ibid.
} 
lain di sekitarnya, sebab pandangan mata hati dapat menembus hal-hal yang tidak bisa dilakukan oleh mata kepala. ${ }^{33}$

\section{Unsur Penggerak Manusia}

Menurut psikoanalisa, terutama Freud, struktur psikis manusia terdiri dari id, ego, dan super ego. Id berisikan dorongan insting biologis dan pengalaman traumatis masa kanak-kanak, ego merupakan kesadaran terhadap realitas kehidupan, sedangkan super ego merupakan kesadaran normatif. Psikoanalisa meyakini bahwa penggerak utama manusia adalah libido atau energi libidal. Penjelasan ini bisa diilustrasikan pada gambar 1.

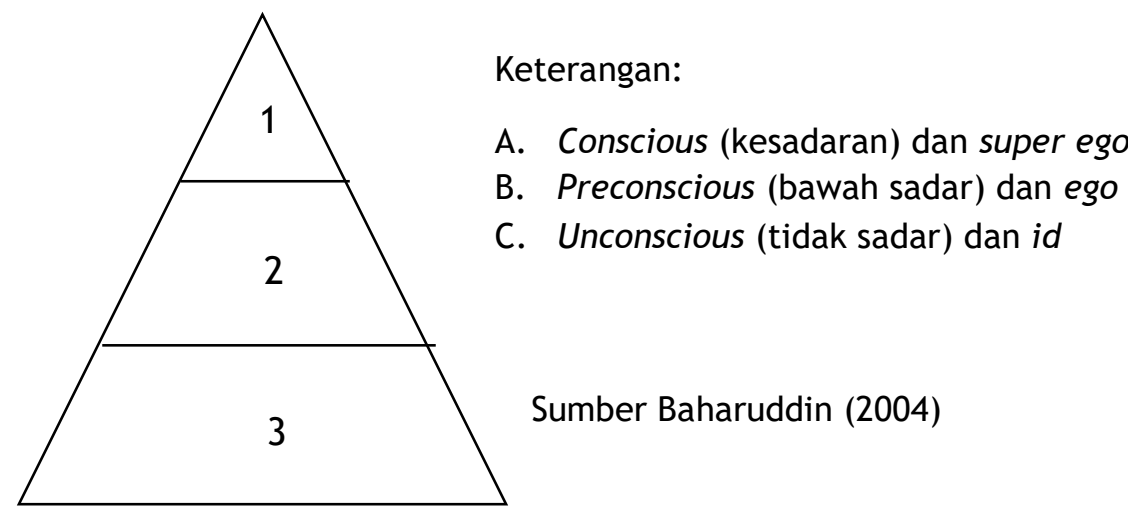

Berbeda dengan psikoanalisa, behavioris memandang psikis manusia merupakan mesin otomatis yang rumit, kompleks dan canggih. Jiwa itu pada mulanya kosong dan diisi dengan pengalaman secara sedikit demi sedikit. Pengalaman-pengalaman itu berhubungan satu dengan lainnya melalui proses asosiasi secara otomatis. Jiwa manusia akan memberikan respon terhadap segala stimulus yang menyentuhnya. Respon itu akan diberikan sesuai dengan perbendaharaan pengalaman yang telah tersusun dalam jiwa manusia. Penjelasan ini bisa diilustrasikan pada gambar 2.

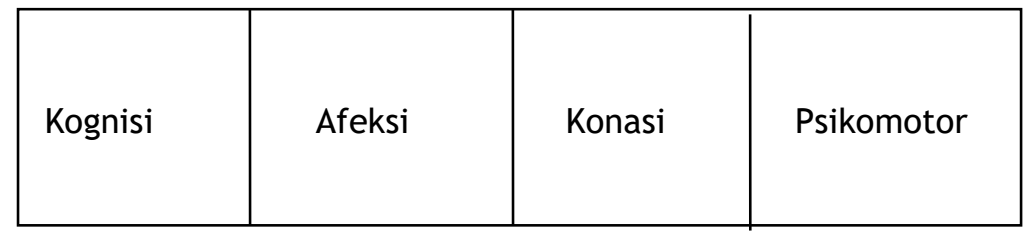

Sumber Baharuddin (2004)

33 Ibid.

El Banat Vol. 11 No. 1 (2021)

$30 \mid$ 
Psikologi humanis, memandang struktur jiwa manusia tersusun dari somatis (raga), psikis (jiwa), neotik (rohani atau spiritual). Ketiga aspek tersebut melahirkan karakteristik jiwa manusia, berupa: gagasan, kreativitas, nilai hidup, pengalaman transcendental, rasa malu, kesadaran diri, tanggungjawab, hati nurani, makna hidup, cinta, semangat, humor, rasa seni dan lain-lain. Ketiga aspek tersebut melahirkan kemauan dan kebebasan, dan potensi untuk memecahkan persoalan hidupnya. Tidak kalah penting, adalah munculnya keyakinan akan nilai-nilai dan prinsip-prinsip moral yang berlaku umum dan untuk seluruh umat manusia. Penjelasan ini ini diilustrasikan pada gambar 3.

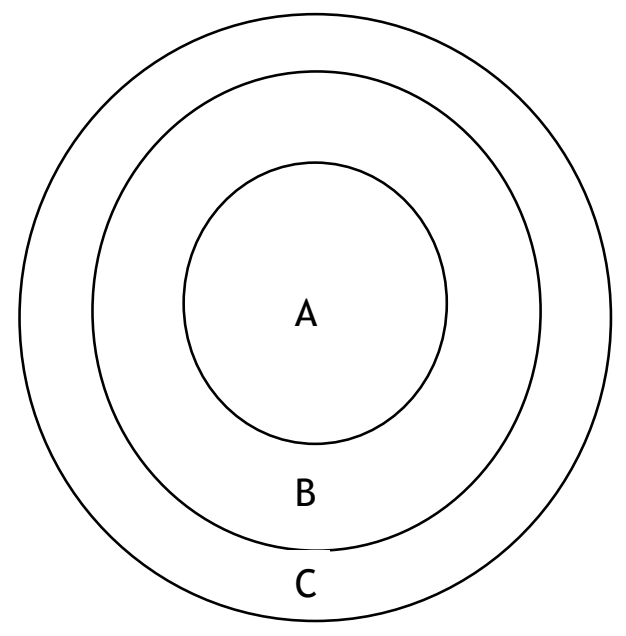

Ketarangan:

a. Dimensi neotik (Spiritual)

b. Dimensi Psikis (Kejiwaan)

c. Dimensi Somatis (raga)

Sumber Baharuddin (2004)

Berbeda dengan psikoanalisa, behavioris, dan humanis, psikologi Islam memandang unsur penggerak manusia adalah ruh. Ruh merupakan dimensi spiritual manusia yang memiliki sifat illahiyah memiliki daya menarik dan mendorong unsurunsur lain untuk mewujudkan sifat-sifat ke-Tuhan-an dalam diri manusia. Pemilikan sifat Tuhan bermakna memiliki potensi-potensi luhur batin. Potensi-potensi itu melekat pada dirmensi-dimensi psikis manusia dan memerlukan aktualisasi pada jisim manusia.

Perwujudan dari sifat-sifat dan daya-daya tersebut pada gilirannya memberikan potensi secara internal di dalam dirinya utuk menjadi khalifah Allah. Khalifah Allah dapat berarti mewujudkan sifat-sifat Allah secara nyata dalam kehidupannya di bumi untuk mengelola dan memanfaatkan bumi Allah. Dengan adanya ruh ini mampu menundukkan sisi hayawan pada manusia. Dengan adanya ruh pada diri manusia, 
menyebabkan manusia menjadi makhluk yang istimewa, unik, dan mulia. Inilah yang disebut sebagai khalqan akhar, yaitu makhluk yang istimewa yang berbeda dengan makhluk lainnya ${ }^{34} \mathrm{Al}$-Qur'an menjelaskan hal ini dalam surat Al-Mu'minun ayat 12-14:

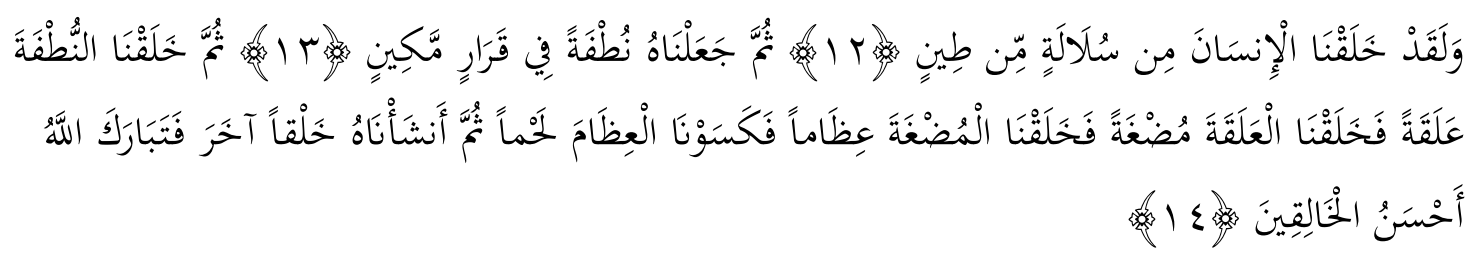

"Dan sesungguhnya Kami telah menciptakan manusia dari suatu saripati (berasal) dari tanah. Kemudian Kami jadikan saripati itu air mani (yang disimpan) dalam tempat yang kokoh (rahim). Kemudian air mani itu Kami jadikan segumpal darah, lalu segumpal darah itu Kami jadikan segumpal daging, dan segumpal daging itu Kami jadikan tulang belulang, lalu tulang belulang itu Kami bungkus dengan daging. Kemudian Kami jadikan dia makhluk yang (berbentuk) lain. Maka Maha Sucilah Allah, Pencipta Yang Paling Baik."

Selain ruh sebagai unsur penggerak manusia, menurut Baharuddin, ${ }^{35}$ motivasi juga berperan mengarahkan perilaku dan tingkah laku manusia. Psikologi Islam dekat dengan humanistik, yang memandang kebutuhan-kebutuhhan yang rendah sampai kepada kebutuhan tertinggi, yaitu kebutuhan religious atau agama. Bila dalam Humanistik motivasi utama manusia adalah aktualisasi diri, dalam psikologi Islam, motivasi utama manusia adalah ibadah. Hal ini dipahami karena struktur psikis manusia dalam psikologi Islam lebih lengkap dari struktur manusia dalam psikologi humanistik. Sama halnya dengan psikologi humanistik, bahwa motivasi utama itu merupakan konsekuensi logis dari dimensi spiritual, yaitu dimensi terakhir dan tertinggi dari dimensi psikis manusia, maka bagi psikologi Islam, motivasi utama berupa ibadah itu bersumber dari dimensi fitrah yakni dimensi terakhir manusia.

Secara fitrah menurut Najati, ${ }^{36}$ manusia memiliki kesiapan (potensi) untuk mengenal dan beriman kepada Allah subhanahu wa ta'ala. Secara fitrah manusia juga berpotensi untuk bertauhid, mendekatkan diri kepada Allah, kembali kepada Nya, dan meminta pertolongan kepada Nya ketika dalam situasi genting. Al-Qur'an telah mengisyaratkan adanya potensi yang dimiliki manusia untuk beragama, seperti yang terfirman dalam QS. Al-Rum: 30:

\footnotetext{
${ }^{34}$ Baharuddin, Paradigma Psikologi Islami Studi Tentang Elemen Psikologi Dari Al-Quran.

35 Ibid.

${ }^{36}$ Muhammad Utsman Najati, Psikologi Dalam Tinjauan Hadits Nabi (Jakarta: Mustaqim, 2003). 


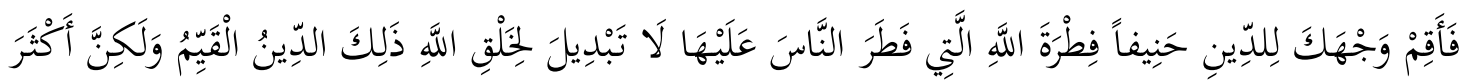

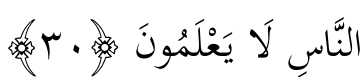

"Maka hadapkanlah wajahmu dengan lurus kepada agama (Allah); (tetaplah atas) fitrah Allah yang telah menciptakan manusia menurut fitrah itu. Tidak ada perubahan pada fitrah Allah. (Itulah) agama yang lurus; tetapi kebanyakan manusia tidak mengetahui"

Dalam menafsirkan ayat tersebut, Al-Qurthubi berpendapat bahwa sesungguhnya pada materi dasar penciptaan dan tabiat dasar manusia, terkandung potensi untuk mengetahui adanya Allah, mengimani, dan mentauhidkan Nya. Hal ini bisa dia peroleh melalui pengamatan terhadap makhluk-makhluk Allah yang sangat mengagumkan. ${ }^{37}$

Dengan demikian, motivasi tersebut bukan hanya menyentuh aspek lahiriah manusia sebagai makhluk biologis saja, akan tetapi mampu menjadi generator manusia sebagai makhluk biologis, psikis, dan spiritual. Sapuri ${ }^{38}$ menjelaskan, kesehatan manusia seutuhnya dalam perkembangan kepribadian seseorang mempunyai empat pilar, yaitu: (1) sehat secara jasmani/ fisik (biologis), (2) sehat secara kejiwaan (psikologis), (3) sehat secara sosial, dan (4) sehat secara spiritual (kerohanian atau agama). Dengan empat pilar tersebut, manusia pantas menyandang nilai-nilai kemanusiaan. Manusia akan selalu berada diambang kehancuran tanpa pembekalan yang baik dari keempat unsur tersebut. Unsur yang perlu perhatian tinggi adalah sehat secara spiritual/ kerohanian. Rohani sehat dan dikembangkan dengan baik akan membentuk seseorang yang jauh lebih maju dan baik.

Konsep-konsep Islam tentang motivasi didapat melalui uraian akan kebutuhan tertinggi manusia di akhirat dan juga melalui janji-janji Allah subhanahu wa ta'ala yang tertulis dalam Al-Qur'an. Karena dasar psikologi Islam adalah spiritual, dalam membentuk pola motivasi Islami pun harus berdiri di atas garis spiritual. ${ }^{39}$ Apabila psikologi Barat menekankan motivasi pada garis fisik biologis dan kognitif (kejiwaan), dalam psikologi Islam penekanannya pada kebutuhan jiwa dan ruh juga dilakukan. Pada hakikatnya kedua unsur ini menuntut manusia untuk memenuhi kebutuhannya juga.

37 Ibid.

${ }^{38}$ Sapuri, Psikologi Islam Tuntunan Jiwa Manusia Modern.

39 Tobroni, "Spiritual Leadership: A Solution of The Leadership Crisis in Islamic Education in Indonesia," British Journal of Education 3, no. 11 (2015): 40-53; Tobroni, “Memperbincangkan Pemikiran Pendidikan Islam Dari Idealisme Substantif Hingga Konsep Aktual." 


\section{E. Kesimpulan}

Islam memberikan khazanah yang tidak terbatas bagi ilmu psikologi. Meskipun awalnya tidak dijumpai istilah psikologi, tetapi dikenal di dalam dunia Islam sebagai ilmu al-Nafs, atau pada masa lalu dikenal dengan llmu al-Akhlaq dan tasawuf yang tidak bicara teoretis, tetapi lebih aplikatif yang mewarnai kehidupan kaum muslim hingga sekarang ini. Semua perangkat ilmu tersebut dapat direkonstruksi ulang dengna menambah khazanah psikologi kontemporer. Jadi berangkatnya dari khazanah Islam baru menggunakan psikologi kontemporer sebagai kerangka saintifikasi agar dikomunikasikan secara universal. Ilmu psikologi yang dibangun dalam epistemologi Barat sebatas menyelidiki aspek jamani dan psikis manusia. Akan tetapi psikologi Islam memberikan pandangan yang lebih luas. Psikologi Islam mampu merambah pada aspek ruhaniyah bahkan dimensi esoteris pada manusia. Memasuki babak keempat dalam periodesasi psikologi menurut Baharuddin, hingga saat ini psikologi Islam patut untuk dikaji dan terus dikembangkan.

\section{F. Referensi}

Abdullah, Asep Abbas, Abdul Muhid, and Rangga Sa'adillah. "Dissecting Implicit Meaning in Tembang Dolanan: A Discourse Analysis." LiNGUA: Jurnal Ilmu Bahasa dan Sastra 16, no. 1 (2021): 61-74. https://ejournal.uinmalang.ac.id/index.php/humbud/article/view/10247.

Al-Faruqi, Ismail Raji. Islamization of Knowledge General Principle and Work Plan. Bandung: Pustaka Pelajar, 1984.

Azis, Abd., AR, Zaini Tamin, \& Muksin. “Genealogi Carok di Madura; Perspektif Psikologi Sosial". Al Ibrah:Jurnal Pendidikan dan Keilmuan Islam, Vol. 5, No. 1 (2020).

Baharuddin. Paradigma Psikologi Islami Studi Tentang Elemen Psikologi Dari Al-Quran. Yogyakarta: Pustaka Pelajar, 2004.

Bakry, Mubassyirah. “Konsep Al-Nafs (Jiwa) Dalam Filsafat Islam.” Jurnal Al-Asas III, no. 1 (2015): 135-150.

Bolotio, Rivai. “Analisis Pendidikan Dalam Konsep Pendidikan Jiwa,” 2000.

Dalyono. Psikologi Pendidikan. Vol. Cet. Jakarta: PT Rineka Cipta, 2005.

Halim, Fatimah. "Kajian Kritis Terhadap Pemikiran Tentang Jiwa (Al-Nafs) Dalam Filsafat Islam." Al Daulah: Jurnal Hukum Pidana dan Ketatanegaraan 1, no. 2 (2013): 60-73. http: //journal.uinalauddin.ac.id/index.php/al_daulah/article/view/1424/1379. 
Hergenhahn, B. R., \& Olson, M. H. An Introduction to Theories of Learning. P. Janzow. New Jersey: Prentice-Hall International, Inc., 1997.

Hidayat, Bahril. Psikologi Islam. Pekanbaru, 2014.

Husni, Desma. "Pengukuran Konsep Amanah Dalam Pendekatan Kualitatif Dan Kuantitatif." Jurnal Psikologi 43, no. 3 (2016): 194-206.

M, Afrizal. "Pemikiran Para Filosof Muslim Tentang Jiwa." An-Nida - Jurnal Pemikiran Islam 39, no. 1 (2014): 1-17.

Najati, Muhammad Utsman. Psikologi Dalam Tinjauan Hadits Nabi. Jakarta: Mustaqim, 2003.

Purnamasari, Nia Indah. "Signifikansi Teori Belajar Clark Hull dan Ivan Pavlov bagi Pendidikan Islam Kontemporer”. Qudwatuna: Jurnal Pendidikan Islam, Vol. 3, No. 1, (2020): 1-24.

Purwanto, Y. Epistemologi Psikologi Islami Dialektika Pendahuluan Psikologi Barat Dan Psikologi Islami. Edited by A. Susana. Bandung: PT Refika Aditama, 2007.

Putra, Rangga Sa'adillah Sandhy Atma. “Pembelajaran Pendidikan Agama Islam Melalui Pendekatan Saintifik Dalam Membentuk Sikap Spiritual Siswa Sekolah Menengah Atas Di Sidoarjo (Studi Fenomenologi Pengalaman Guru Dan Siswa Pada SMA Di Sidoarjo)." Universitas Muhammadiyah 2020. http://eprints.umm.ac.id/65683/.

---. “Pendekatan Saintifik Dalam Perspektif Pendidikan Islam.” Universitas Islam Negeri Sunan Ampel Surabaya, 2014. http://digilib.uinsby.ac.id/846/.

Rosidin. Epistemologi Pendidikan Islam. Yogyakarta: Diandra Kreatif, 2013.

S.A.P., Rangga Sa'adillah, Tobroni, Ishomuddin, and Khozin. "The Meaning Construction of a Scientific Approach on Teaching Islamic Education." International Journal of Psychosocial Rehabilitation 24, no. 09 (2020): 2525-2532.

S.A.P., Rangga Sa'adillah, Dewi Winarti, and Daiyatul Khusnah. "Kajian Filosofis Konsep Epistemologi Dan Aksiologi Pendidikan Islam." Journal of Islamic $\begin{array}{lllll}\text { Civilization } & 3, & \text { no. } & 1 & \text { (2021): }\end{array}$ https: / / journal2.unusa.ac.id/index.php/JIC/article/view/2135.

Sapuri, R. Psikologi Islam Tuntunan Jiwa Manusia Modern. Jakarta: PT Raja Grafindo Persada, 2009.

Supriyono, Abu Ahmadi \& W. Psikologi Belajar. Jakarta: PT Rineka Cipta, 2013.

Tobroni. "Spiritual Leadership: A Solution of The Leadership Crisis in Islamic Education in Indonesia." British Journal of Education 3, no. 11 (2015): 40-53.

Tobroni, D. “Memperbincangkan Pemikiran Pendidikan Islam Dari Idealisme Substantif Hingga Konsep Aktual.” Jakart: Prenada Media group (2018).

Wahab, Abdur Rahman Shaleh \& M. A. Psikologi Suatu Pengantar Dalam Perspektif Islam. Jakarta: Kencana, 2004. 
Rangga Sa'adillah S.A.P., dkk.

Yudiani, Erna. "Dinamika Jiwa Dalam Perspektif Psikologi Islam." Jia 1 (2013). 